\title{
Permeability coefficients and vapor pressure determination for fragrance materials
}

Rafael N. Almeidaa ${ }^{*}$, João G. M. Hartza , Patrícia F. Costa ${ }^{b}$, Alírio E. Rodrigues ${ }^{c}$, Rubem M. F. Vargas ${ }^{a}$, Eduardo Cassela

aUnit Operations Lab, Polytechnic School, Pontifical Catholic University of Rio Grande do Sul, Av. Ipiranga 6681 - Prédio 30, Bloco F, Sala 208, Porto Alegre, Brazil

${ }^{\mathrm{b} C B Q F}$ - Centro de Biotecnologia e Química Fina - Laboratório Associado, Escola Superior de Biotecnologia, Universidade Católica Portuguesa/Porto, Rua Dr. António Bernardino Almeida, 4200-072 Porto, Portugal

CLSRE-Laboratory of Separation and Reaction Engineering, Associate Laboratory LSRE/LCM, Faculdade de Engenharia, Universidade do Porto, Rua Dr. Roberto Frias, 4200465, Porto, Portugal

${ }^{*}$ Corresponding author: Rafael N. Almeida. r.nolibos@edu.pucrs.br. Tel.: +55 5133534585. FAX: +55 (51) 3320.3823

E-mails: joao.hartz@edu.pucrs.br; pfsantoscosta@gmail.com; arodrig@fe.up.pt; rvargas@pucrs.br; cassel@pucrs.br.

This article has been accepted for publication and undergone full peer review but has not been through the copyediting, typesetting, pagination and proofreading process, which may lead to differences between this version and the Version of Record. Please cite this article as doi: $\underline{10.1111 / \text { ICS. } 12686}$

This article is protected by copyright. All rights reserved 
MR. RAFAEL NOLIBOS ALMEIDA (Orcid ID : 0000-0002-5792-5392)

Article type : Original Article

\section{Permeability coefficients and vapor pressure determination for fragrance materials}

\section{Abstract}

OBJECTIVE: This study aims to correlate new experimental data relevant to the description of the combined evaporation/permeation process of a perfume applied onto the skin.

METHODS: The vapor pressure data was measured by thermogravimetric analysis (TG-DTA). The Antoine constants and the Clarke \& Glew parameters were determined for the same set of fragrance molecules to describe its low vapor pressures at new temperature ranges. The permeability coefficient of a set of 14 fragrance molecules in ethanolic solution was determined by Franz diffusion cell experiments, using porcine skin. The samples were analyzed by gas chromatography with a flame ionization detector (GC/FID) and high-performance liquid chromatography with UV visible detector (HPLC/UV). A QSAR model was proposed to correlate the experimental data.

RESULTS: The Antoine constants were determined and presented low standard deviations. The Clarke \& Glew physically significant parameters were obtained along with its statistical analysis. The fitting is good since the magnitude order is in accordance with the literature, associated with the low correlation between the estimated parameters and low standard deviations. The presented correlation, based on a mixture using only ethanol as solvent, showed better results than previous QSAR This article is protected by copyright. All rights reserved 
models with a standard relative deviation $\left(\sigma_{r}\right)$ of 0.190 , a standard error (SE) of 0.397 , and a determination coefficient $\left(\mathrm{R}^{2}\right)$ of 0.7786 .

CONCLUSION: The dataset is still small compared to larger and more general QSAR models; however, it is much more specific as to the type of solvent and class of materials studied. This work represents an advance for the modeling of the perfume diffusion process since it specifies important properties that until then had been treated in a more general way.

Keywords: Evaporation, Penetration, Perfume, Franz diffusion cell, Computer modelling, Statistics

\section{Introduction}

The description of the combined phenomena of fragrance evaporation/permeation is complex due to its chemical nature, the interaction with other formulation ingredients, subtracts (e.g., clothing) and external factors (e.g. temperature) [1,2]. Regarding the use of a perfume, two main processes describe the phenomena: evaporation and absorption. The evaporation process is clearly dependent on the fragrance concentration in the liquid phase, as well as external factors such as temperature, wind, and other surface properties. On the other hand, the absorption of any chemical through the skin depends upon multiple factors (skin hydration, transepidermal water loss, temperature), and it determines the amount of fragrance substances available for human perception, since it also impacts the liquid phase concentration.

Most of the perfume raw materials (PRMs) used in cosmetic products have a lipophilic character and, therefore, the potential to be absorbed through the skin. Due to this feature, terpenes - some of the main perfume constituents - are even used as skin permeation enhancers in transdermal drug delivery [3]. The literature vastly explores this property by measuring the permeability coefficient of drugs enhanced by the terpene lipophilic property [4-6]. Due to the lipophilic nature of skin, the optimal permeant has relatively low molecular weight and reasonable solubility in both hydrophilic and lipophilic media [7]. The permeability coefficient of a substance is also strongly dependent on the vehicle it is dissolved in, due to the solvent or solid-matrix 
interactions and the permeation enhancement/decreasing factor [8]. The permeation and safety of various PRMs have been investigated [9-11]. The process controlling parameters are also well determined: physicochemical properties (including size, lipophilicity, and solubility in oil and in water), the vehicle in which it is dissolved in, the "skin environment", and the extent of exposure [12].

Several predictive permeation models have been proposed on cutaneous drug delivery and toxicology [13-15]. However, such models are more reliable when confined within well-defined chemical classes, and their applicability is often limited by the narrow property space of the set of permeants under study $[16,17]$. Mathematical models describing the absorption of chemicals through the skin have been also reported in the literature [15,18-20], but just a few kinetic models describe the combined fragrance evaporation/permeation phenomena [2,21].

The evaporation process of volatiles at atmospheric pressure relies on the interface vapor-liquid equilibrium. Such systems are easily represented by the modified Raoult's law, which requires the pure components vapor pressure and the mixture activity coefficients [22]. Group contribution methods (UNIFAC) or predictive models (COSMO-SAC) are used to predict the mixture property [23]. However, few data are available for the terpenes vapor pressure, and the corresponding states/group contribution methods frequently demand other unspecified properties [24]. The thermogravimetric analysis (TG-DTA) has been proved to be a useful tool for determining low vapor pressure, because it is a fast test and requires small samples $[25,26]$. There are studies applying the TG-DTA technique through a modified Langmuir equation, to evaluate the vapor pressure of terpenes and essential oils $[27,28]$.

Recently, a mathematical model based on a differential mass balance for predicting the evaporation and permeation profiles of fragrance systems applied to skin was reported [29]. In this previous study, three fragrance systems were studied: ethanol/limonene, ethanol/linalool, and ethanol/a-pinene. This method requires the terpene permeability coefficient $\left(K_{p}\right)$ to estimate the whole diffusion system. As far as we know, this is the only study regarding the specific evaluation of permeability coefficients for terpenes in ethanolic solutions. The correlations for its estimation available in the literature are poorly accurate for lipophilic compounds, once they were This article is protected by copyright. All rights reserved 
developed for aqueous systems, mostly for pharmaceuticals and hydrophilic substances. The International Fragrance Association (IFRA) uses the correlation developed based on the findings of the Research Institute of Fragrance Materials (RIFM) [30], which gathers data regarding the safety of fragrance materials, along with the EDETOX [31] database (containing in vitro and in vivo percutaneous penetration data). In addition, the enhancer effect attributed to terpenes in pharmaceutical formulations is also observed for perfumes, proving that $K_{p}$ values are also related to the vehicle $[7,32]$. For this reason, a correlation for $K_{p}$ values specific for terpenes in ethanolic solutions would represent a breakthrough.

Therefore, this investigation aims to evaluate the two main properties, vapor pressure and permeability coefficient, related to the evaporation/permeation process concerning ethanolic solutions of PRMs applied to the skin. A Quantitative StructureActivity Relationship (QSAR) based on the two main current models $[30,33]$ is proposed in order to correlate the experimental data, only when ethanol is used as the vehicle. Antoine constants and Clarke and Glew parameters [34] are fitted to the experimental low vapor pressure data. The determination of these two properties aims to aid in the design and evaluation of fragrance materials [35].

\section{Materials and methods}

\section{Chemicals}

Camphor (96\%), carvacrol (99\%), (L)-carvone (99\%), E-caryophyllene ( $\geq 98 \%$ ), citronellol $(\geq 95 \%)$, eucalyptol $(99 \%)$, eugenol $(\geq 98 \%)$, geraniol $(\geq 97 \%)$, R-(+)limonene $(\geq 98 \%)$, $( \pm)$-linalool (>97\%), ( \pm )-menthol $(\geq 98 \%)$, (-)-menthone $(96 \%)$, $\alpha$ pinene $(98 \%)$, tonalide $(\geq 98 \%)$, vanillin $(99 \%)$, and Tween $^{\circledR} 20$ were all obtained from Sigma-Aldrich. Ethanol (P.A. 99.8\%), 1-propanol (67-63-0 $\geq 99.5 \%)$, methanol (67-56-1

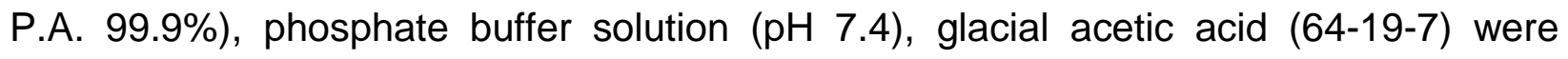
obtained from Merck. The perfume raw materials are listed in Table I with their chemical structure presented in Fig. 1. All the PRMs are miscible with ethanol (Hazardous Substances Data Bank (HSDB) and Joint FAOMHO Expert Committee on Food Additives (JECFA)), with exception of vanillin and camphor solubilities, $50 \mathrm{mg} \mathrm{mL}^{-1}$ (Sigma® product datasheet) and $1 \mathrm{~g} \mathrm{~mL}^{-1}$ (HSDB).

This article is protected by copyright. All rights reserved 


\section{Figure 1}

\section{Table 1}

Pig ears skin preparation

The pig ears were obtained from the local slaughterhouse Cooperativa Ouro do Sul Carnes (Harmonia, RS, Brazil) within few hours post-mortem. No approval of the ethics committee of animal research was required as the ears were taken from pigs not slaughtered specifically for the purpose of this study. Ears were washed with water, and any visible hairs were trimmed carefully with scissors and scalpel. The full-thickness skin of the dorsal side was removed from the underlying cartilage using a scalpel and served as the starting material for further preparation. Then, the stratum corneum (SC) was isolated by trypsin treatment as recommended by Kligman and Christophers [36]. For that, the SC facing upward was saturated with trypsin solution $(0.5 \%$ in phosphate buffer at $\mathrm{pH} 7.4)$ in a glass Petri dish and stored for $4 \mathrm{~h}$ at $37{ }^{\circ} \mathrm{C}(310.15 \mathrm{~K})$ in a saturated vapor atmosphere. The digestion occurred from the dermis end of the tissue, ensuring that the SC remained undamaged. The top layer representing the SC was carefully removed using forceps and washed with purified water. The tissue was washed again with purified water and stored in aluminium foil at $253 \mathrm{~K}$.

\section{In vitro skin permeation}

In vitro skin permeation assays were carried out on Franz diffusion cells with an orifice diameter of $9 \mathrm{~mm}$, corresponding to a skin area of $0.64 \mathrm{~cm}^{2}$, and a receptor volume of $15.0 \mathrm{~mL}$ was used in the diffusion cell experiments. Two jacketed cells were mounted in a magnetic stirrer (MS-H280-Pro - DLAB) and kept at $33^{\circ} \mathrm{C}(306.15 \mathrm{~K})$, to mimic human skin surface temperature, by means of circulating water from a thermostatic water bath (TECNAL TE-2000). The skin was placed horizontally on Franz diffusion cells, between the donor and receptor compartments. The receptor solution was composed of phosphate buffer solution ( $\mathrm{pH} 7.4)$, Tween ${ }^{\circledR} 20$ and 1-propanol (97:2:1 w/w), and were equipped with small Teflon-coated magnets, maintaining the receptor medium thoroughly stirred during the entire experiment. In this study, the fragrance systems 
studied had the initial concentrations of $10 \mathrm{mg} \mathrm{mL}^{-1}$ (ethanolic solution). The applied volume to the skin was $2 \mathrm{~mL}$ of solution for the infinite dose experiments. The infinite dose experiments aim to define the permeability coefficient in steady state; the donor solution large volume is not representative of the product and this exposure scenario was determined just in order to maintain the external concentration constant over the $24 \mathrm{~h}$ and to establish a steady-state flux. The fragrance system was capped with parafilm and tin foil in order to avoid the evaporation or photodegradation over time. For the liquid phase analysis, aliquots of $1 \mathrm{~mL}$ were withdrawn from the receptor medium at fixed times (i.e., 0, 1, 2, 4, 6, 24 h) with a syringe, and immediately replaced with an equivalent amount of fresh buffer solution.

\section{Quantification}

The fragrance components in the liquid phase were firstly isolated by liquid-liquid extraction with the addition of $1 \mathrm{~mL}$ of cyclohexane to $1 \mathrm{~mL}$ of receptor phase. The mixture was submitted to a vigorous vortex agitation for $1 \mathrm{~min}, 10 \mathrm{~min}$ of ultrasonic bath, followed by $24 \mathrm{~h}$ freezing in order to improve phase separation [37]. The organic phase containing the target compounds was then analyzed using an Agilent 7890A gas chromatograph (Agilent Technologies, USA). The injector used was in split mode (1:10) at $523 \mathrm{~K}$. The capillary column used was a HP-5MS (30 m x $250 \mu \mathrm{m}$ i.d., $0.25 \mu \mathrm{m}$ phase thickness, Agilent Technologies, USA), coated with $5 \%$ phenyl methyl silane. The oven temperature started at $333 \mathrm{~K}$, raised to $523 \mathrm{~K}_{\text {at }} 20 \mathrm{~K} \mathrm{~min}^{-1}$, then held for $2 \mathrm{~min}$. Carrier gas was Helium with a flow rate of $1 \mathrm{~mL} \mathrm{~min}{ }^{-1}$. The FID detector was maintained at 523 $\mathrm{K}$. The quantification of the components was achieved using the respective calibration curve, using concentrations of $10,5,2.5,1.25,0.625,0.312$ and $0.152 \mathrm{mg} \mathrm{mL}^{-1}$ of each terpene dissolved in the receptor buffer solution, and isolated as above described for the samples.

In the case of vanillin and tonalide, which have higher boiling points, the analysis was carried out by HPLC/UV. An Agilent Technologies 1200 Series with an Agilent Zorbax Eclipse XDB-C18 (5 $\mu \mathrm{m}, 150 \times 4,6 \mathrm{~mm})$ column was used. The analysis methodology was the same as used by [38]. The UV wavelengths used were 231 and $252 \mathrm{~nm}$, for the vanillin and tonalide, respectively. The mobile phase consisted of two solvents with a flow rate of $1 \mathrm{~mL} \min ^{-1}$ : (A) water: acetic acid (98: 2), (B) methanol: This article is protected by copyright. All rights reserved 
acetic acid (98: 2). The flow starts at $40 \%$ of solvent $A$ and decreases constantly to $0 \%$ in $5 \mathrm{~min}$ when it increases until $40 \%$ in the next $5 \mathrm{~min}$. The ratio $40 \%$ of Solvent $A$ and $60 \%$ of Solvent B is then kept constant for $5 \mathrm{~min}$. Each run lasted $15 \mathrm{~min}$ [38]. To quantify the samples, calibration curves were made using the $\geq 98 \%$ standards.

\section{Vapor pressure}

The vapor pressure of each compound was experimentally determined by thermogravimetry with differential thermal analysis (TG-DTA) using the TA Instruments STD Q600 equipment. For that, $10 \mathrm{mg}$ of samples were placed in an alumina crucible with a cross-sectional area of $0.28 \mathrm{~cm}^{2}$, with a heating rate of $10 \mathrm{~K} \mathrm{~min}^{-1}$, in an atmosphere of nitrogen with a $50 \mathrm{~mL} \mathrm{~min}{ }^{-1}$ flow and temperature ranging from 293 to $573 \mathrm{~K}$. The Langmuir equation (Eq. 1) relates the vapor pressure, at a given temperature, to the mass loss rate [26]. The constant $k$ was determined per calibration with a well-known compound (E-caryophyllene) following the same methodology.

$$
P_{\text {exp }}{ }^{s a t}=k\left[\left(\frac{T}{M W}\right)^{\frac{1}{2}}\left(\frac{d m}{d t}\right)\right]
$$

where, $P_{\text {exp }}{ }^{\text {sat }}$ is the experimental TG-DTA vapor pressure $(\mathrm{Pa}), T$ is the temperature $(\mathrm{K}), M W$ is the molar weight $\left(\mathrm{g} \mathrm{mol}^{-1}\right)$ and $\frac{d m}{d t}$ is the mass loss rate $\left(\mathrm{g} \mathrm{s}^{-1}\right)$.

The Antoine equation (Eq. 2) was used to model the obtained vapor pressure curve.

$$
\ln \left(P^{s a t}\right)=A-\frac{B}{T+C}
$$

where $P^{\text {sat }}$ is the vapor pressure $(\mathrm{Pa}), T$ is the temperature $(\mathrm{K}), \mathrm{A}, \mathrm{B}$ and $\mathrm{C}$ are adjustable parameters. These three parameters are highly correlated, and they are not physically significant, despite the good model adherence. In this way, several different models were proposed for a better property description. Clarke and Glew [34] have proposed a model based on the evaluation of thermodynamic functions from equilibrium constants, initially presented for chemical reactions but lately expanded for pure This article is protected by copyright. All rights reserved 
compounds [39] describing the equilibrium between the two phases. The most significant model improvement is the parameters physical representation; $d G_{\theta}^{0}$ is the Gibbs free energy of the phase change process, $d H_{\theta}^{0}$ is the enthalpy involved in the process and $d C_{p, \theta}^{0}$ is the specific heat of the gas formed in the process, all at the reference temperature $\theta$ which corresponds to a reference pressure $P^{0}$, as presented by Eq. 3 .

$$
\ln \left(\frac{P^{s a t}}{P^{0}}\right)=-\frac{d G_{\theta}^{0}}{\theta}+d H_{\theta}^{0}\left(\frac{1}{\theta}-\frac{1}{T}\right)+d C_{p, \theta}^{0}\left(\frac{\theta}{T}-1+\ln \left(\frac{T}{\theta}\right)\right)
$$

Due to the nonlinearity of the models used to describe this property, there are few works that assess the statistical significance of the estimated parameters, which could be performed using a hybrid estimation method. The particle swarm optimization method [40] is used first to provide a set of initial guesses, which is used for fine-tuning of model parameters with the help of a Gauss-Newton procedure [41].

\section{Permeability coefficient and QSAR model}

The diffusion process involving the skin - considered as a simple membrane - occurs in accordance with Fick's first law, which can be described in terms of permeability (related to diffusivity) as shown by Eq. 4.

$$
J(t)=K_{p, i}\left(C_{i, d}(t)-C_{i, r}(t)\right)
$$

where $K_{p, i}$ is the skin permeability coefficient $\left(\mathrm{cm} \mathrm{h}^{-1}\right)$ and $C_{i, d}$ and $C_{i, r}$ are the component $i$ concentrations in the donor and receptor chambers $\left(\mathrm{mg} \mathrm{cm}^{-3}\right)$, respectively. The maximum flux at which a material diffuses across the skin is theoretically achieved when it is maintained as a saturated solution on the surface $\left(C_{i, d} \gg C_{i, r}\right)$. The infinite dose condition leads to a constant mass flux trough the membrane after a diffusion lag time [42].

The flux $J\left(\mathrm{mg} \mathrm{cm}^{-2} \mathrm{~h}^{-1}\right)$ is then calculated from the slope of cumulative uptake of a substance through a unit of skin surface area $\left(Q \mathrm{in} \mathrm{mg} \mathrm{cm}^{-2}\right)$ as a function of time, 
once the maximum flux is established (constant mass transfer rate) and a linear behavior is recorded. The permeability coefficient is then obtained from Eq. 5, which gives:

$$
K_{p, i}=\frac{J}{C_{i, d}}=\frac{Q}{\Delta t C_{i, d}}
$$

A finite dose model, which accounts quantitatively for depletion of chemical due to skin uptake and its evaporation from the skin surface was presented by and, among other properties, it requires permeability coefficient data [29]. The experimental flux for each substance is obtained from the in vitro skin permeation experiments (Franz diffusion cell). From these experimental data, a Quantitative Structure-Activity Relationship (QSAR) is proposed based on the significant properties related to the absorption of fragrance compounds into the skin. Guy [33] proposed a correlation in order to predict the rate and extent of fragrance absorption, in which it is also pointed out that chemicals with the highest values of steady-state flux have the highest values of vapor pressure. Based on the previous assumptions proposed by the RIFM [30] and Guy [33], the molecular weight (MW) and the octanol-water partition coefficient were considered for this new proposal.

\section{Results and discussion}

\section{Vapor pressure}

The experimental vapor pressure of all the studied perfume raw materials were determined by the TG-DTA technique. All the compounds presented a zero-order kinetics, which can be attributed to the evaporation. An example of nonzero-order kinetics is a thermal dissociation process. Since sublimation and evaporation are zeroorder processes, the rate of mass loss of a sample due to vaporization should be constant, providing that the free surface area does not change. In this way, the absence of chemical decomposition was evaluated in terms of its kinetics, as stated by different papers before $[25,27,43,44]$.The Langmuir equation (Eq. 1) relates the vapor pressure at a given temperature to the rate of mass loss from the thermogravimetric tests. The 
percentage mass loss and its derivative $\left(\% \mathrm{~K}^{-1}\right)$ are presented in Fig. 2. A calibration constant was used for the specific method and equipment $\left(k=4.971 \times 10^{4} \mathrm{~Pa} \mathrm{~g}^{-0.5} \mathrm{~mol}^{-0.5}\right.$ $\left.\mathrm{s}^{-1} \mathrm{~K}^{-0.5}\right)$.

Figure 2

The Antoine vapor pressure curve for all the compounds were built based on Eq. 2. Although the vapor pressure of several PRMs is available in literature, most of the existing data belongs to that of room temperatures $(298.15 \mathrm{~K})$ and the atmospheric pressure. Eugenol and carvone were selected in order to compare the obtained results with those reported in the literature (Fig. 3). The Antoine constants were estimated (Table II), along with its standard relative deviations.

\section{Table II}

\section{Figure 3}

The experimental and estimated values obtained from public sources such as PubChem, ChemSpider, and EpiSuite were all investigated. For these compounds, the experimental values presented are mostly at room temperature (293.15 or $298.15 \mathrm{~K}$ ). Estimated values from correlations and predictive models are also available at these sources, but as discussed by Almeida et al. [45], at low temperatures the error of such models increases and should only be used when no experimental data is available. At the NIST database, a few Antoine constants are available at higher temperature ranges (camphor, carvone, carvacrol, eugenol, menthol) and only a-pinene presents Antoine constants for the same temperature range.

The resulting parameters of the Clarke and Glew equation (Eq. 3) along with the standard deviation of the fit, $\sigma_{r}$, are presented in Table III. Some of the compounds used in this study have similar data reported in the literature [46-49], however the vapor pressure experimental data ware obtained by different methods, or at different 
temperature ranges. The most relevant estimated parameter, the enthalpy of vaporization, of ten of the studied molecules are available at the NIST database, although the reference temperature is not the same (all of them are determined at higher temperatures). This property is mostly used in the thermodynamic modeling of separation processes, such as distillation, along with the vapor pressure. In case of a more complex model for the diffusion of perfume from the skin, including heat and mass transfer, the enthalpy of vaporization is required.

\section{Table III}

The correlation coefficient obtained from the covariation matrix for each pair of parameters results in 42 correlation coefficients in the range of -0.7396 to 0.8751 , for the set of 14 compounds. The fitting is good, since the magnitude order is in accordance with the literature, associated with the low correlation between the estimated parameters and low standard deviations. The confidence region for the carvacrol is presented in Fig. 4, where the more circular and less elliptical the region, the better the fitting.

\section{Figure 4}

The vapor pressure data is fundamental regarding the modeling of perfume diffusion process from skin, but it is also important concerning the modeling of any mass transfer process associated to the phase equilibrium such as distillation or any other separation process. In this way, the collected data and curve fitting comprehend an advance towards a better representation of different systems and applications.

Permeability coefficient

The experimental permeability coefficient $\left(K_{p}^{e x p}\right)$ was calculated for all the compounds from the infinite dose Franz cell experiments. The infinite dose condition allows a constant permeation of a substance through the skin surface once the maximum flux is established and a linear behavior is recorded. The permeability coefficient for each substance was then obtained according to Eq. 5. Table IV presents the results for the experimental values, along with the relative volatilities at $25^{\circ} \mathrm{C}(298.15 \mathrm{~K})$, which are more available in this condition and it can be obtained from its standard vapor pressure.

This article is protected by copyright. All rights reserved 
Fig. 5 illustrates the results for the citronellol and geraniol as representative of all the studied perfume raw materials.

\section{Figure 5}

\section{Table IV}

The experimental values agreed with those expected when compared to the two main current models recommended by the RIFM (Research Institute for Fragrance Materials), which assists the regulation of safety assessment process. The SAM (skin absorption model) [30] is an extension from the one developed by Guy [33], being both based on a dataset of "fragrance-like" materials. The two models are of great importance in the toxicological field, serving as guideline along with the parameters used in the threshold of toxicological concern (TTC) technique [11] for the safety evaluation of cosmetic ingredients. The EDETOX and RIFM's datasets are bigger than the one presented here, however most of the experimental data is obtained with different vehicles and most of them do not present the experimental values of $K_{p}$ (the permeability coefficients were then calculated using predicted water solubility values and experimental maximum absorption flux).

One of the main goals of the present work is to correlate the experimental fragrance material data obtained from the permeation experiments with an ethanolic solution, an essential solvent of perfumes. In our previous work, a model for the combined process of permeation and evaporation from skin was proposed [29]. Differences were found between the experimental permeability coefficients and those obtained by Guy [33], and the relevance of the vehicle-skin interaction, as well as the saturation on the surface were demonstrated.

In this way, a new correlation (Eq. 6), for the use only when ethanol is present as vehicle and inside the specific ranges of $\log k_{\text {ow }}(1.21-5.70)$ and $M W_{i}(136.2-258.4 \mathrm{~g}$ $\mathrm{mol}^{-1}$ ), is proposed based on the experimental permeability coefficients obtained in this work:

This article is protected by copyright. All rights reserved 


$$
\log K_{p}=-2.383+0.294 \log k_{o w}-0.00094 M W_{i}
$$

The presented correlation has a standard relative deviation $\left(\sigma_{r}\right)$ of 0.190 , a standard error (SE) of 0.397 and a determination coefficient $\left(\mathrm{R}^{2}\right)$ of 0.7786 (Fig. 6). The two previous models, Guy (SE $\left.=0.712, \mathrm{R}^{2}=0.578\right)$ and $\mathrm{SAM}\left(\mathrm{SE}=0.594, \mathrm{R}^{2}=0.703\right)$, presented slightly worse results although based on a larger dataset.

\section{Figure 6}

In order to validate the proposed correlation, three compounds from the RIFM and EDETOX database were selected (coumarin, isoeugenol and musk ketone). Comparing the values obtained through SAM and the correlation proposed in this work, the permeability coefficient differences vary from 2 to $11 \%$. It is important to note that for the same compound under different experimental conditions, different values are found in the literature. For this reason, the application of experimental values (whenever possible) or the use of a correlation that best suits the studied system is highly recommended [30]. The reader is cautioned that the experimental $\mathrm{Kp}$ values in this report or those predicted by Eq. 6 must not be used as a substitute for aqueous Kp values when conducting risk assessments according to the method of Guy [32] or Shen et al. [33]. They will not yield comparable results.

The results suggest that the proposed correlation is a complementary tool in the assessment of permeability coefficients specifically for the design of fragrance systems. The present work does not intend to replace the SAM model, which is mainly developed for toxicological purposes, instead it was designed to assist during pre-formulation stages of scented products using ethanol as vehicle. The QSAR model meets the principles for validation (according to the OECD), has a defined endpoint, an unambiguous algorithm, and a well-defined domain of applicability (perfumes). It has also appropriate measures of goodness-of-fit and a mechanistic interpretation. The dataset used for the SAM correlation has 131 compounds (54 fragrance materials and 72 "fragrance-like" materials), 27 of which had an experimentally determined $K_{p}$ on different solvents (ethanol/water solution, PEG, acetone). Most of the RIFM database consists of toxicological experiments in which the main goal is to determine the amount

This article is protected by copyright. All rights reserved 
absorbed from the applied dose (permeability coefficient is not determined). The experimental data and the correlation presented in this work are a first step towards achieving a more specific range of applicability, and thus becoming available for predictions of perfume raw materials when in ethanol solution.

\section{Conclusions}

In this work, a range of fragrance chemicals had its vapor pressure and permeability coefficients determined. The permeability coefficients were assessed by Franz diffusion cell experiments, measuring the steady-state flux through the skin and using a simple mathematical model based upon Fick's first law of diffusion. Low vapor pressures were evaluated by thermogravimetric analysis and a modified Langmuir equation. The dataset is still small compared to larger and more general QSAR models; however, it is much more specific as to the type of solvent and class of materials studied. The QSAR model proposed presented good fitting to the experimental data and lower errors ( $\mathrm{SE}=0.397$ and $\mathrm{R}^{2}=0.7786$ ) than more general models (Guy correlation and Skin Absorption Model).

\section{References}

1. Costa, P., Velasco, C.V., Loureiro, J.M. and Rodrigues, A.E. Effect of cosmetic matrices on the release and odour profiles of the supercritical $\mathrm{CO}_{2}$ extract of Origanum majorana L. Int. J. Cosmet. Sci. 38, 364-374 (2015).

2. Kasting, G.B. and Miller, M.A. Kinetics of finite dose absorption through skin 2: Volatile compounds. J. Pharm. Sci. 95, 268-280 (2006).

3. Chen, J., Jiang, Q.D., Chai, Y.P. et al. Natural terpenes as penetration enhancers for transdermal drug delivery. Molecules. 21, 1709-1720 (2016).

4. Pandit, J., Aqil, M. and Sultana, Y. Terpenes and essential oils as skin penetration enhancers. In: Percutaneous penetration enhancers chemical methods in penetration enhancement. (Dragicevic, N., Maibach, H.I.), pp. 173-193. SpringerVerlag Berlin, Heidelberg (2015).

This article is protected by copyright. All rights reserved 
5. Schmitt, S., Schaefer, U., Doebler, L. and Reichling, J. Cooperative Interaction of Monoterpenes and Phenylpropanoids on the in vitro Human Skin Permeation of Complex Composed Essential Oils. Planta Med. 75, 1381-1385 (2009)

6. Vaddi, H.K., Ho, P.C. and Chan, S.Y. Terpenes in propylene glycol as skinpenetration enhancers: Permeation and partition of haloperidol, fourier transform infrared spectroscopy, and differential scanning calorimetry. J. Pharm. Sci. 91, 1639-1651 (2002).

7. Lalko, J., Brain, K., Green, D. and Api, A.M. In Vitro Human Skin Penetration of the Fragrance Material Linalool In Vitro Human Skin Penetration of the Fragrance Material Linalool. Toxicologist. 102, 309-312 (2008).

8. Cal, K., Janicki, S. and Sznitowska, M. In vitro studies on penetration of terpenes from matrix-type transdermal systems through human skin. Int. J. Pharm. 224, 81-88 (2001).

9. Bickers, D.R., Calow, P., Greim, H.A. et al. The safety assessment of fragrance materials. Regul. Toxicol. Pharmacol. 37, 218-273 (2003).

10. Frasch, H.F. Dermal absorption of finite doses of volatile compounds. J. Pharm. Sci. 101, 2616-2619 (2012).

11. Kroes, R., Renwick, A.G., Feron, V. et al. Application of the threshold of toxicological concern (TTC) to the safety evaluation of cosmetic ingredients. Food Chem. Toxicol. 45, 2533-2562 (2007).

12. Potts, R.O. and Guy R.H. Predicting Skin Permeability. Pharm. Res. 9, 663-669 (1992).

13. Russell, L.M. and Guy, R.H. Measurement and prediction of the rate and extent of drug delivery into and through the skin. Expert Opin. Drug Deliv. 6, 355-369 (2009).

14. Grégoire, S., Ribaud, C., Benech, F. et al. Prediction of chemical absorption into and through the skin from cosmetic and dermatological formulations. Br. J.

This article is protected by copyright. All rights reserved 
Dermatol. 160, 80-91 (2009).

15. Lian, G., Chen, L. and Han, L. An evaluation of mathematical models for predicting skin permeability. J. Pharm. Sci. 97, 584-598 (2008).

16. Geinoz, S., Guy, R.H., Testa, B. and Carrupt, P.A. Quantitative StructurePermeation Relationships (QSPeRs) to Predict Skin Permeation: A Critical Evaluation. Pharm. Res. 21, 83-92 (2004).

17. Riviere, J.E. and Brooks, J.D. Predicting Skin Permeability from Complex Chemical Mixtures: Dependency of Quantitative Structure Permeation Relationships on Biology of Skin Model Used. Toxicol. Sci. 119, 224-232 (2011).

18. Bartosova, L. and Bajgar, J. Transdermal Drug Delivery In Vitro Using Diffusion Cells. Curr. Med. Chem. 19, 4671-4677 (2012).

19. Chen, L., Lian, G. and Han, L. Modeling transdermal permeation. Part I. Predicting skin permeability of both hydrophobic and hydrophilic solutes. AIChE J. 56, 1136-1146 (2009).

20. Mitragotri, S., Anissimov, Y.G., Bunge, A.L. et al. Mathematical models of skin permeability: An overview. Int. J. Pharm. 418, 115-129 (2011).

21. Saiyasombati, P. and Kasting, G.B. Two-stage kinetic analysis of fragrance evaporation and absorption from skin. Int. J. Cosmet. Sci. 25, 235-243 (2003).

22. Poling, B.E., Prausnitz, J.M. and O'connell, J.P., 5 ed. The properties of gases and liquids. McGraw-Hill, New York (2001).

23. Gerber, R.P. and Soares, R.P. Prediction of infinite-dilution activity coefficients using UNIFAC and COSMO-SAC variants. Ind. Eng. Chem. Res. 49, 7488-7496 (2010).

24. Li, P., Ma, P.S., Yi, S.Z. et al. A new Corresponding-States Group-Contribution method (CSGC) for estimating vapor pressures of pure compounds. Fluid Phase Equilib. 101, 101-119 (1994)

25. Phang, P., Dollimore, D. and Evans, S.J. A comparative method for developing This article is protected by copyright. All rights reserved 
vapor pressure curves based on evaporation data obtained from a simultaneous TG-DTA unit. Thermochim. Acta. 392, 119-25 (2002).

26. Price, D.M. Vapor pressure determination by thermogravimetry. Thermochim. Acta. 367, 253-262 (2001).

27. Hazra, A., Dollimore, D. and Alexander, K. Thermal analysis of the evaporation of compounds used in aromatherapy using thermogravimetry. Thermochim. Acta. 392, 221-229 (2002).

28. de Oliveira, C.E.L. and Cremasco, M.A. Determination of the vapor pressure of Lippia gracilis Schum essential oil by thermogravimetric analysis. Thermochim. Acta. 577, 1-4 (2014).

29. Almeida, R.N., Costa, P., Pereira, J. et al. Evaporation and Permeation of Fragrance Applied to the Skin. Ind. Eng. Chem. Res. 58, 9644-9650 (2019).

30. Shen, J., Kromidas, L., Schultz, T. and Bhatia, S. An in silico skin absorption model for fragrance materials. Food. Chem. Toxicol. 74, 164-176 (2014).

31. EDETOX. Available at: https://research.ncl.ac.uk/edetox/

32. Brain, K.R., Walters, K.A., Green, D.M. et al. Percutaneous penetration of diethanolamine through human skin in vitro: application from cosmetic vehicles. Food Chem. Toxicol. 43, 681-690 (2005).

33. Guy, R.H. Predicting the rate and extent of fragrance chemical absorption into and through the skin. Chem. Res. Toxicol. 23, 864-870 (2010).

34. Clarke, E.C.W. and Glew, D.N. Evaluation of thermodynamic functions from equilibrium constants. Trans. Faraday Soc. 62, 539-547 (1966).

35. Frasch, H.F. and Bunge, A.L. The Transient Dermal Exposure II: Post-Exposure Absorption and Evaporation of Volatile Compounds. J. Pharm. Sci. 104, 14991507 (2015).

36. Kligman, A.M. and Christophers, E. Preparation of isolated sheets of human stratum corneum. Arch. Dermatol. 88, 702-705 (1963).

This article is protected by copyright. All rights reserved 
37. Zhang, K., Abraham, M.H. and Liu, X. An equation for the prediction of human skin permeability of neutral molecules, ions and ionic species. Int. J. Pharm. 521, 259-266 (2017).

38. Waliszewski, K.N., Pardio, V.T. and Ovando, S.L. A simple and rapid HPLC technique for vanillin determination in alcohol extract. Food Chem. 101, 10591062 (2007).

39. de Kruif, C.G. and Blok, J.G. The vapour pressure of benzoic acid. J. Chem. Thermodyn. 14, 201-206 (1982).

40. Kennedy, J. and Eberhart, R. Particle swarm optimization. In: Proceedings of ICNN'95-International Conference on Neural Networks. IEEE 1942-1948 (1995).

41. Prata, D.M., Pinto, J.C. and Lima, E.L. Comparative analysis of robust estimators on nonlinear dynamic data reconciliation. Comput. Aided Chem. Eng. 25, 501506 (2008).

42. Hansen, S., Lehr, C.M. and Schaefer, U.F. Improved input parameters for diffusion models of skin absorption. Adv. Drug. Deliv. Rev. 65, 251-264 (2013).

43 Chatterjee, K., Hazra, A., Dollimore, D. and Alexander, K.S. Estimating vapor pressure curves by thermogravimetry: a rapid and convenient method for characterization of pharmaceuticals. Eur. J. Pharm. Biopharm. 54, 171-180 (2002).

44 Phang, P. and Dollimore, D. The calculation of the vapor pressures of antioxidants over a range of temperatures using thermogravimetry. Thermochim. Acta. 367-368, 263-271 (2001).

45 Almeida, R.N., Soares, R.D.P. and Cassel, E. Fractionation process of essential oils by batch distillation. Brazilian J. Chem. Eng. 35, 1129-1140. (2018).

46. Štejfa, V., Fulem, M., Růžička, K. and Červinka, C. Thermodynamic study of selected monoterpenes III. J. Chem. Thermodyn. 79 280-289 (2014).

47. Štejfa, V., Fulem, M. and Růžička, K. Thermodynamic study of selected This article is protected by copyright. All rights reserved 
monoterpenes IV. J. Chem. Thermodyn. 144, 106013 (2020).

48. Štejfa, V., Dergal, F., Mokbel, I. et al. Vapor pressures and thermophysical properties of selected monoterpenoids. Fluid Phase Equilib. 406, 124-133 (2015).

49. Štejfa, V., Fulem, M., Růžička, K. et al. Thermodynamic study of selected monoterpenes. J. Chem. Thermodyn. 60, 117-125 (2013).

This article is protected by copyright. All rights reserved 
Table I. Properties of the fragrance materials. Molecular Weight $(\mathrm{MW})$, Vapor Pressure $\left(P_{i}^{\text {sat }}\right)$ at $25^{\circ} \mathrm{C}$ and Octanol-Water Partition Coefficient $\left(K_{\text {ow }}\right)$.

\begin{tabular}{cccccc}
\hline Compound & CAS\# & Molecular formula ${ }^{\mathrm{a}}$ & $\mathrm{MW}\left(\mathrm{g} \mathrm{mol}^{-1}\right)^{\mathrm{a}}$ & $P_{i}^{\text {sat }}(\mathrm{Pa})^{\mathrm{b}}$ & $\log K_{\text {ow }}{ }^{\mathrm{c}}$ \\
\hline Camphor & $76-22-2$ & $\mathrm{C}_{10} \mathrm{H}_{16} \mathrm{O}$ & 152.23 & 9.60 & 2.38 \\
Carvacrol & $499-75-2$ & $\mathrm{C}_{10} \mathrm{H}_{14} \mathrm{O}$ & 150.22 & 3.09 & 3.49 \\
Carvone & $99-49-0$ & $\mathrm{C}_{10} \mathrm{H}_{14} \mathrm{O}$ & 154.22 & 13.70 & 2.71 \\
Citronellol & $106-22-9$ & $\mathrm{C}_{10} \mathrm{H}_{20} \mathrm{O}$ & 156.27 & 5.88 & 3.91 \\
Eucalyptol & $470-82-6$ & $\mathrm{C}_{10} \mathrm{H}_{18} \mathrm{O}$ & 154.25 & 253.0 & 2.74 \\
Eugenol & $97-53-0$ & $\mathrm{C}_{10} \mathrm{H}_{18} \mathrm{O}_{2}$ & 164.2 & 3.01 & 2.27 \\
Geraniol & $106-24-1$ & $\mathrm{C}_{10} \mathrm{H}_{18} \mathrm{O}$ & 154.25 & 4.0 & 3.56 \\
Limonene & $5989-27-5$ & $\mathrm{C}_{10} \mathrm{H}_{16}$ & 136.23 & 192.0 & 4.57 \\
Linalool & $78-70-6$ & $\mathrm{C}_{10} \mathrm{H}_{18} \mathrm{O}$ & 154.25 & 21.3 & 2.97 \\
Menthol & $89-78-1$ & $\mathrm{C}_{10} \mathrm{H}_{20} \mathrm{O}$ & 156.27 & 8.49 & 3.2 \\
Menthone & $14073-97-3$ & $\mathrm{C}_{10} \mathrm{H}_{18} \mathrm{O}$ & 154.25 & 0.37 & 3.05 \\
Tonalide & $21145-77-7$ & $\mathrm{C}_{18} \mathrm{H}_{26} \mathrm{O}$ & 258.41 & 0.0471 & 5.70 \\
Vanillin & $121-33-5$ & $\mathrm{C}_{8} \mathrm{H}_{8} \mathrm{O}_{3}$ & 152.15 & 0.057 & 1.21 \\
a-Pinene & $80-56-8$ & $\mathrm{C}_{10} \mathrm{H}_{16}$ & 136.23 & 633.0 & 4.83 \\
Ethanol & $64-17-5$ & $\mathrm{C}_{2} \mathrm{H}_{6} \mathrm{O}$ & 46.1 & 7910 & -0.31 \\
\hline
\end{tabular}

${ }^{\mathrm{a}}$ From EPI Suite Database. ${ }^{b}$ Experimental values from EPI Suite Database, at $25{ }^{\circ} \mathrm{C}$. ${ }^{\mathrm{c}}$ Experimental values of log $K_{\text {ow }}$ from EPI Suite Database.

This article is protected by copyright. All rights reserved 
Table II. Antoine estimated vapor pressure parameters.

\begin{tabular}{cccccc}
\hline Compound & A & B & C & $\begin{array}{c}\text { Temperature } \\
\text { Range }(\mathrm{K})\end{array}$ & $\sigma_{r}{ }^{a}$ \\
\hline Camphor & 28.86 & 7827.78 & 6.59 & $298.1-353.1$ & 0.033 \\
Carvacrol & 27.09 & 8226.41 & 27.86 & $298.1-383.2$ & 0.050 \\
Carvone & 28.08 & 8364.89 & 27.02 & $298.2-308.2$ & 0.019 \\
Citronellol & 23.04 & 6026.10 & 14.10 & $298.1-426.4$ & 0.066 \\
Eucalyptol & 20.57 & 4495.92 & 20.40 & $298.0-381.2$ & 0.087 \\
Eugenol & 26.34 & 7722.42 & 3.59 & $298.1-459.1$ & 0.012 \\
Geraniol & 23.54 & 6374.41 & 20.14 & $298.0-427.7$ & 0.109 \\
Limonene & 26.30 & 6392.22 & 19.97 & $298.1-333.2$ & 0.031 \\
Linalool & 25.26 & 6494.80 & 5.59 & $298.1-423.5$ & 0.022 \\
Menthol & 29.56 & 8648.66 & 12.83 & $298.1-360.0$ & 0.077 \\
Menthone & 29.72 & 8265.75 & 12.66 & $298.2-336.5$ & 0.034 \\
Tonalide & 30.62 & 9400.46 & 12.86 & $298.1-329.0$ & 0.001 \\
Vanillin & 26.79 & 8632.73 & 12.14 & $299.2-355.0$ & 0.004 \\
a-Pinene & 24.27 & 5760.66 & 15.45 & $298.1-372.3$ & 0.064 \\
\hline
\end{tabular}

${ }^{\mathrm{a}} \sigma_{r}$ is the standard relative deviation of the fit defined as $\sigma_{r}=\left[\sum_{i=1}^{n}(\Delta \ln p)^{2}{ }_{i} /(n-m)\right]^{\frac{1}{2}}$, where $\Delta \ln p$ is the difference between logarithms of the experimental and the fitted values, $n$ is the number of experimental points used in the fit and $m$ is the number of adjustable parameters.

This article is protected by copyright. All rights reserved 
Table III. Parameters of Clarke and Glew equation derived from vapor pressure data at the reference temperature $\theta=298.15 \mathrm{~K}$ and pressure $P^{0}=10^{5} \mathrm{~Pa}$.

\begin{tabular}{cccccc}
\hline Compound & $d G_{\theta}^{0}\left(\mathrm{~J} \mathrm{~mol}^{-1}\right)$ & $d H_{\theta}^{0}\left(\mathrm{~J} \mathrm{~mol}^{-1}\right)$ & $d C_{p_{\theta}}^{0}\left(\mathrm{~J} \mathrm{~mol}^{-1} \mathrm{~K}^{-1}\right)$ & $\begin{array}{c}\text { Temperature } \\
\text { Range }(K)\end{array}$ & $\sigma_{r}{ }^{\mathrm{a}}$ \\
\hline Camphor & 20135.0 & 54664.0 & -62.1 & $298.1-353.1$ & 0.451 \\
Carvacrol & 24302.0 & 53398.0 & -38.0 & $298.1-383.2$ & 0.002 \\
Carvone & 22721.0 & 57294.0 & -44.0 & $298.2-308.2$ & 0.243 \\
Citronellol & 22444.0 & 73017.0 & -59.7 & $298.1-426.4$ & 0.124 \\
Eucalyptol & 13850.0 & 37027.0 & -50.7 & $298.0-381.2$ & 0.117 \\
Eugenol & 23622.0 & 65905.0 & -63.6 & $298.1-459.1$ & 0.138 \\
Geraniol & 20447.0 & 62447.0 & -56.3 & $298.0-427.7$ & 0.439 \\
Limonene & 14682.2 & 47239.7 & -67.2 & $298.1-333.2$ & 0.766 \\
Linalool & 20560.0 & 54704.0 & -68.5 & $298.1-423.5$ & 0.008 \\
Menthol & 24809.0 & 65028.0 & -44.4 & $298.1-360.0$ & 0.004 \\
Menthone & 21409.0 & 66924.0 & -45.3 & $298.2-336.5$ & 0.007 \\
Tonalide & 27556.0 & 72133.0 & -35.3 & $298.1-329.0$ & 0.037 \\
Vanillin & 31121.0 & 67998.0 & -37.6 & $299.2-355.0$ & 0.076 \\
a-Pinene & 12333.0 & 44565.0 & -62.7 & $298.1-372.3$ & 0.242 \\
\hline
\end{tabular}

${ }^{\text {a }} \sigma_{r}$ is the standard relative deviation of the fit defined as $\sigma_{r}=\left[\sum_{i=1}^{n}(\Delta \ln p)^{2}{ }_{i} /(n-m)\right]^{\frac{1}{2}}$, where $\Delta \ln p$ is the difference between logarithms of the experimental and the fitted values, $n$ is the number of experimental points used in the fit and $m$ is the number of adjustable parameters.

This article is protected by copyright. All rights reserved 
Table IV. Experimental and correlated skin permeability coefficients of the studied fragrance materials.

\begin{tabular}{ccccccc}
\hline Compound & $\mathrm{MW}\left(\mathrm{g} \mathrm{mol}^{-1}\right)^{\mathrm{a}}$ & $\alpha .10^{4 \mathrm{~b}}$ & $\log \mathrm{Kow}^{\mathrm{c}}$ & $K_{p}^{\text {exp }} .10^{2}\left(\mathrm{~cm} \mathrm{~h}^{-1}\right)$ & $\log K_{p}^{\text {exp }}$ & $\log K_{p}^{\text {calcd }}$ \\
\hline Camphor & 152.23 & 12.14 & 2.38 & 1.0027 & -1.999 & -1.827 \\
Carvacrol & 150.22 & 3.91 & 3.49 & 5.3023 & -1.276 & -1.504 \\
Carvone & 154.22 & 17.32 & 2.71 & 1.6062 & -1.794 & -1.733 \\
Citronellol & 156.27 & 7.43 & 3.91 & 2.3467 & -1.630 & -1.387 \\
Eucalyptol & 154.25 & 319.85 & 2.74 & 1.9617 & -1.707 & -1.715 \\
Eugenol & 164.2 & 3.80 & 2.27 & 2.5244 & -1.598 & -1.869 \\
Geraniol & 154.25 & 5.06 & 3.56 & 4.4223 & -1.354 & -1.487 \\
d-Limonene & 136.23 & 242.73 & 4.57 & 8.0363 & -1.095 & -1.172 \\
Linalool & 154.25 & 26.93 & 2.97 & 0.9671 & -2.015 & -1.657 \\
Menthol & 156.27 & 10.73 & 3.2 & 3.7304 & -1.428 & -1.592 \\
Menthone & 154.25 & 0.467 & 3.05 & 2.1702 & -1.664 & -1.635 \\
Tonalide & 258.41 & 0.059 & 5.7 & 11.0262 & -0.958 & -0.950 \\
Vanillin & 152.15 & 0.072 & 1.21 & 0.6866 & -2.163 & -2.167 \\
a-Pinene & 136.23 & 800.20 & 4.83 & 8.0641 & -1.093 & -1.080
\end{tabular}

${ }^{\mathrm{a}}$ From EPI Suite Database. ${ }^{\mathrm{b}}$ Relative volatility determined from vapor pressure values from EPI Suite Database, at $25{ }^{\circ} \mathrm{C}$. ' Experimental values of log $K_{\text {ow }}$ from EPI Suite Database. ${ }^{d}$ From the correlation proposed in this work.

This article is protected by copyright. All rights reserved 


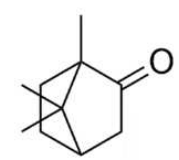<smiles>Cc1ccc(C(C)C)cc1O</smiles><smiles>C=C(C)C1CC=C(C)C(=O)C1</smiles><smiles>CC(C)=CCCC(C)CCO</smiles><smiles>CC12CCC(CC1)C(C)(C)O2</smiles>

Camphor

Carvacrol

Citronellol

Eucalyptol<smiles>C=CCc1ccc(O)c(OC)c1</smiles>
Eugenol<smiles>CC1CCC(C(C)C)C(=O)C1</smiles>

Menthone<smiles>CC(C)=CCC/C(C)=C/CO</smiles><smiles>CC1=CCC2CC1C2(C)C</smiles>

a-Pinene<smiles>C=C(C)C1CC=C(C)CC1</smiles>

Limonene<smiles>C=CC(C)(O)CCC=C(C)C</smiles>

Linalool<smiles>COC1CC(C)CCC1C(C)C</smiles><smiles>CC(=O)c1cc2c(cc1C)C(C)(C)C(C)CC2(C)C</smiles>

Tonalide<smiles>COc1cc(C=O)ccc1O</smiles>

Figure 1. Fragrance chemical structures studied. 


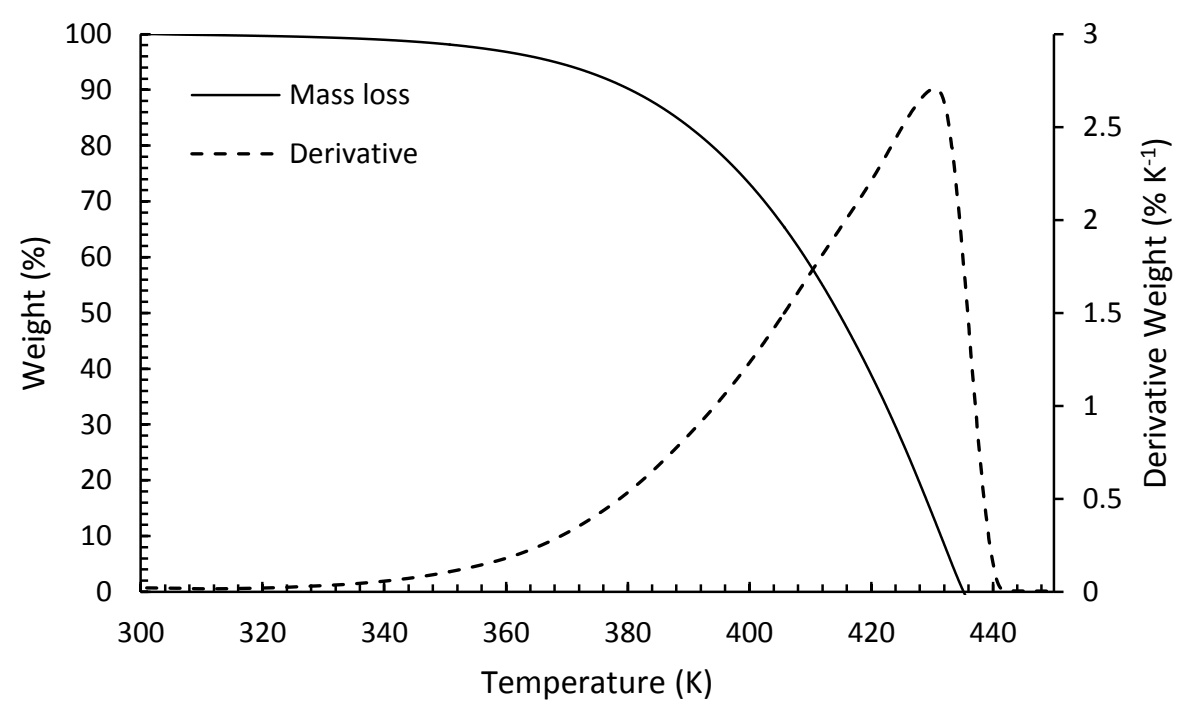

Figure 2. Geraniol TG-DTA analysis. 


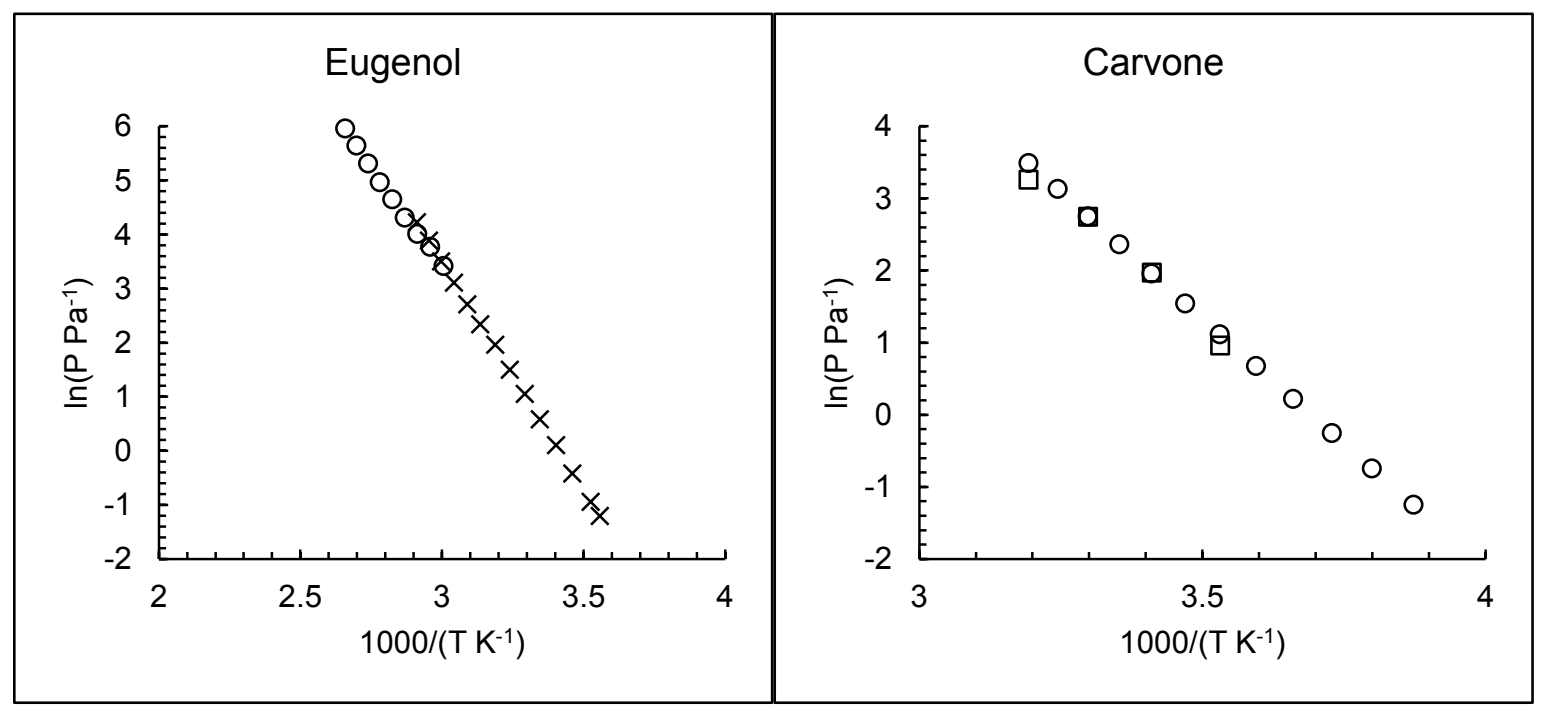

Figure 3. Comparison between experimental and literature vapor pressures of eugenol and Carvone. Experimental data from this work (०); Literature data for eugenol $(\times)[43]$ and carvone $(\square)$ [44]. 

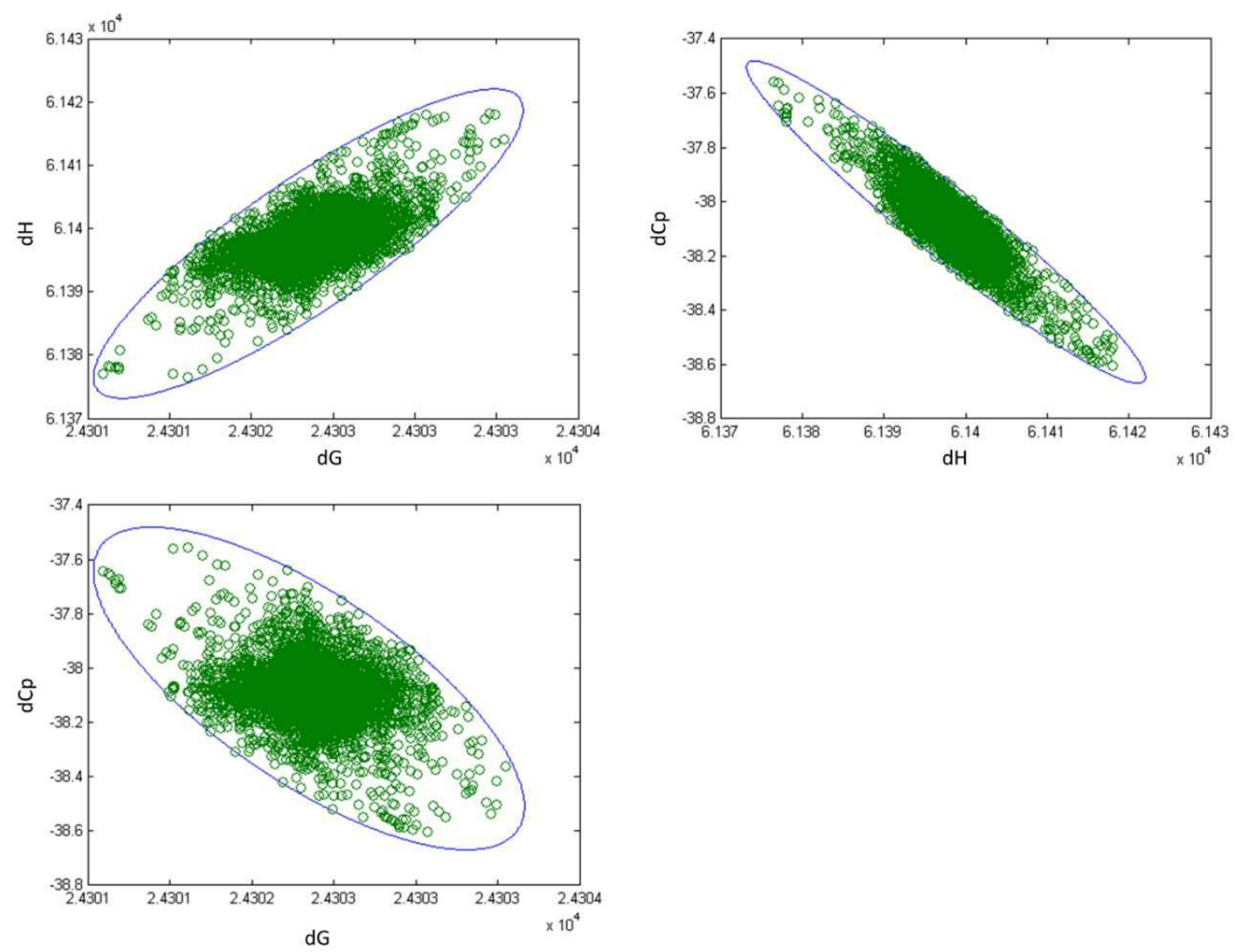

Figure 4. Confidence regions for the Clarke and Glew fitted parameters for the carvacrol vapor pressure data at the reference temperature $\theta=298.15 \mathrm{~K}$ and pressure $P^{0}=10^{5} \mathrm{~Pa}$. 


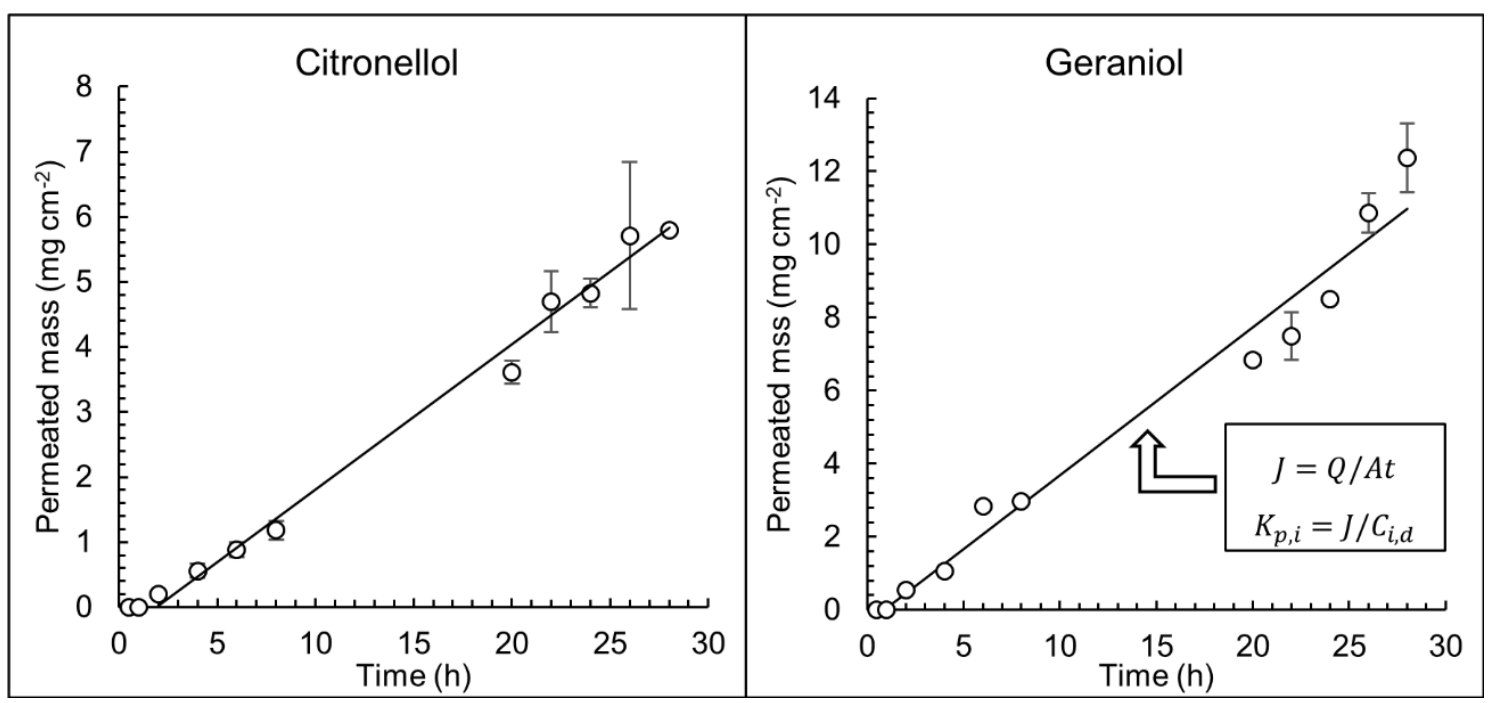

Figure 5. Citronellol and geraniol cumulative amount absorbed at the receptor compartment for the infinite dose experiment. Experimental data $(\circ)$ and continuous line representing the constant mass rate (maximum flux). 


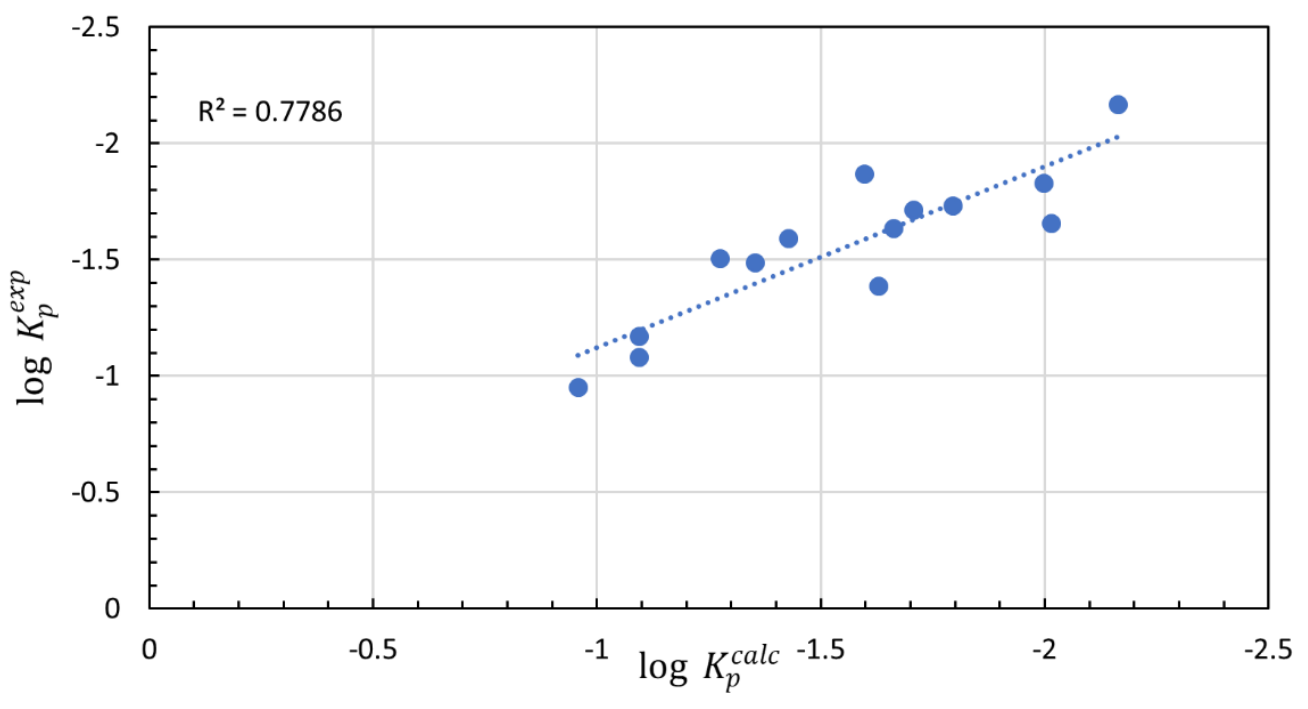

Figure 6. The correlation of experimental values vs estimated values of $\log K_{p}$. 